International Journal of Biology, Pharmacy and Allied Sciences (IJBPAS)

'A Bridge Betueen Caboratory and QRendo'

WWW.ijbpas.com

\title{
A REVIEW ON BIOFERTILIZER FROM COWDUNG
}

BHILALA L ${ }^{1}$, UPADHAYAY ${ }^{2}$, BHATTACHARYA ${ }^{2}$, ANDHARE ${ }^{2}$ AND MARCHAWALA $\mathbf{F}^{2 *}$

1: Student, MSc Biotechnology, Parul Institute of Applied Sciences, Parul University, Post Limda, Waghodia, Gujarat, 391760

2: Assistant Professor, Parul Institute of Applied Sciences, Parul University, Post Limda, Waghodia, Gujarat, 391760

*Corresponding Author: Farhat Marchawala: E Mail: farhat.marchawala82133@paruluniversity.ac.in;

Tel: $+\mathbf{9 1 8 7 5 8 7 3 7 4 6 2}$

Received $21^{\text {st }}$ Jan. 2021; Revised 23 ${ }^{\text {rd }}$ Feb. 2021; Accepted $24^{\text {th }}$ March 2021; Available online $1^{\text {st }}$ April 2021

\section{https://doi.org/10.31032/IJBPAS/2021/10.4.1025}

ABSTRACT

Generally cow dung is used as organic manure to enhance soil fertility in tropical agriculture. Cow dung contains a diverse group of microorganisms such as bacteria, fungi and yeast that canact as aplant growth promoting microbes having traits such as P-solubilization, $\mathrm{Zn}$ solubilization. Research revealed that Bacillus subtilis, Bacillus cereus, Trichoderma harzianum and Aspergillus niger isolated from cow dung can increase the growth of plants. Microorganisms in biofertilizers improve the nutrientvalue of soil. The main sources of biofertilizers are bacteria, fungi and cyanobacteria (blue-green algae). The most prominent relationship that these have with plants is symbiosis, in which the associates get benefits from one another. Biofertilizers provides nutrient to the soil and stimulate plant growth by increasing efficient uptake or availability of nutrients for the plants and by suppressing soil borne diseases. Generally biofertilizers supplement nutrients by fixing atmospheric nitrogen, by phosphorus solubilisation, and by producing plant growth-promoting substances.

Keywords: Biofertilizer, Cow Dung, PGPB, P-Solubilization, N-Fixation \section{INTRODUCTION}

Over the centuries, farmers have harvested so many crops that they have been forced to use modern fertilizers consisting of chemicals, but in the end this chemical 
fertilizers affect the soil as well as plant growth too. The major problem faced by using chemical fertilizers not only affects the soil but human beings as well. Biofertilizers came as the solution, to overcome problem faced by farmers. According to the Vedic text, Gomeya /cow dung is not a waste, but purifies all waste from the environment [1]. Normally, cow dung composition is about $80 \%$ water and array of undigested plant material that is rich in nutrients, microorganisms and their by-products. A total of 24 different minerals like nitrogen and potassium, as well as the detection of sulphur content, magnesium, iron, cobalt, copper, and manganese are found in cow dung. It is used as a fertilizer in Indian countries for centuries. The addition of cow dung increases the mineral content in the soil andenriches plant resistance against pests and diseases. It accelerates plant growth and other beneficial functions such as sulphur oxidation and phosphorus solubilisation. Presence of naturally occurring beneficial microorganisms, predominantly bacteria, actinomycetes, yeasts and certain fungi have been reported in cow dung. Micro flora of cow dungcovers about 60 species of bacteria such as Bacillus spp., Corynebacterium psp., Lactobacillus spp., few fungal spp., (Aspergillus and Trichoderma), about100 species of protozoa and few yeasts [2].
Bacillus subtilis present in cow dung has several useful functions, which includesbio control, promotes plant growth, phosphorus (P) solubilisation, sulphur (S) oxidation and produce industrially important enzymes (amylase and cellulase). Normally aged cow dung is containing several plant growth promoting microbes that live in soil such as bacteria, fungi, Trichoderma and Actinomycetes [3].

Bacteria promotes plant growth by fixing biological nitrogen, by synthesising phytohormones, environmental stress relief, synergism with other bacteria-plant interactions, by inhibiting synthesis of plant ethylene and by increasing availability of nutrients like phosphorus, iron and minor elements, and growth improvement by volatile compounds. Plant growth promoting bacteria enhances the plant vegetative and reproductive growth factors by colonizing plant roots.Today, over the past decade bacterial genera such as Bacillus, Pseudomonas, Azotobacter, Klebsiella, Enterobacter, Arthrobacter, Burkholderia, Azotobacter Serratia, etc. had been used as biofertilizers as report acknowledged from many authors and these isolates are known as PGPB [1]. In agriculture, cow dung can act as manure, biofertilizer, biopesticide, pestrepellent, raw material in biogas generation and as a source of energy. 


\section{Biofertilizers}

As the term Biofertilizer implies,it is ecofriendly, low-cost, renewable source of plant nutrients that supplement chemical fertilizers.Biofertilizers keep the soil environment rich altogethervarieties of micro and macro-nutrients via nitrogen fixation, phosphate and potassium solubilisation or mineralization, release of plant growth regulating substances, production of antibiotics and biodegradation of organic matter in the soil. Biofertilizers are applied directly to seed or soil inoculants; that not only improves soil fertility, but also plays an important role in improving soil nutrition and crop yield [4]. It contains live and effective formulates of bacteria, algae and fungi either individually or in mixture that is capable of atmospheric nitrogen fixation, phosphorus solubilisation, decompose organic material or oxidize sulphur and on application will enrich the availability of nutrients for the plants.

In another words, biofertilizer or microbial fertilizer is a substance composed of living microorganisms (fungi, bacteria, and actinomycetes) and mixture of biodegradable substances. That applied to seed, plant shoots or soil, colonizes the internal part of the plant, via various mechanisms such as rhizospehere, intercellular spaces, increase availability of major nutrients to the host plant to enhance growth and yield of the plant [5]. Through such activities within soil or rhizosphere, biofertilizers produce nutrients like nitrogen, phosphorus and potassium within soil and make them available to the plants. Some microorganisms and their association with plants are being used in the production of biofertilizers. Based on nature and function they classified in different groups.

\section{Nitrogen-Fixing Microbes}

Nitrogen is most abundant in the air, but it limits nutrients because it is difficult for plants to repair and absorb, but some microorganisms can come into contact with plants which are capable of nitrogen fixation. This helps the plant to uptake fixed nitrogen and reduces loses by denitrification, leaching, and volatilization. These microbes fix nitrogen symbiotically. Nitrogen biofertilizers produce the right level of nitrogen in the soil. Nitrogen can be a limiting factor in plant growth, because plants need a certain amount of nitrogen in the soil to grow. The choice of nitrogen biofertilizer depends on the crop used, because different biofertilizers have different effects on soils. Rhizobia used for legume crops are Azotobacter, Azospirillum and Bacillus for non-legume crops, Acetobacter for sugarcane and blue-green algae and Azolla for lowland rice paddies [4].

\section{Phosphorus-Solubilizing Microbes}

In the soil, thephosphorus content is high, but most of it is available in inaccessible 
forms, after nitrogenwhich it is the second most limiting plant nutrient. The phosphorus-solubilizing bacteria (PSB) like Bacillusand Pseudomonas can increase phosphorus access to plants by activating it from the inaccessible forms in the soil [6]. These microbes and certain soil fungi such as Penicillium and Aspergillus bring about dissolution of bound phosphates in soil by emitting natural acids described by lower $\mathrm{pH}$ in their region. The use of the economical rock phosphate with a PSB, Bacillus megaterium var. phosphaticum to sugarcane, was found to build sugar yield and squeeze quality by $12.6 \%$, and it decreased the phosphorus essential by $25 \%$, therefore further causing a half decrease of the costly superphosphate use [8]. Recently a few phosphate-solubilizing microorganism's strains having a place with the genera Bacillus, Rhodococcus, Arthrobacter, Serratia, Chryseobacterium, Gordonia, Phyllobacterium and Delftia were reported [7-9]. These authors additionally recognized different kinds of natural acids delivered by bacterial strains, for example, citric acid, Gluconic acid, lactic, succinic and propionic acids.

Table 1: Microorganisms isolated from cow dung and their functional activities

\begin{tabular}{|c|c|c|}
\hline Microorganism & Functional activity & Reference \\
\hline Bacillus subtilis & Phosphorus solubilization & {$[6]$} \\
\hline Bacillus megaterium & Phosphorous solubilization & {$[10]$} \\
\hline Bacillus safensis & IAA production & {$[10]$} \\
\hline Bacillus cereus & IAA production & {$[10]$} \\
\hline Paenibacillus favisporus sp. & Enzyme production & {$[1]$} \\
\hline Trichoderma harzianum & Nitrogen fixation & {$[11]$} \\
\hline
\end{tabular}

Other Mineral-Solubilizing Biofertilizers

Soil-based microorganisms can be used as modern fertilizers to produce many substances other than nitrogen and phosphorus, such as potassium, zinc, iron, and copper. Some rhizobacteria can convert insoluble potassium into soluble form, which is another supplement that is essential for plant growth.The higher biomass yields because of expanded potassium participation have been seen with Bacillus edaphicus (for wheat), Paenibacillus glucanolyticus (for dark pepper), another Another important mineral in vaccines with Paenibacillus glucanolyticus (for black pepper) and phosphate-soluble Bacillus megaterium (for eggplant, pepper, cucumber) is Bacillus mucilaginosus [7]. Another significant mineral is zinc, which is available at a low focus in the Earth's outside layer, because of which it is remotely applied as the higher dissolvable zinc sulfate to defeat its inadequacies in plant. Nonetheless, a few organisms, for example, Bacillus subtilis, Thiobacillus thiooxidans, and Saccharomyces spp. can solubilize insoluble less expensive zinc intensifies like zinc oxide, zinc carbonate, and zinc sulphide in soil [2]. During processing, it 
produces a medium with protons (which causes hydrolysis) and natural acids (which regulate the formation of cations and place it in a decomposed state), which is important for plant. Rice production and grain yield due to inflammatory damage to silica and soil additives were observed by chain digestion of Bacillus subtilis combined with a mixture of rice grass silica, rice husks, and dark debris.

\section{Compost Biofertilizers}

Biofertilizers are also used for improvement of compost and for enhancement of the bacterial processes that break down the compost waste. Appropriate biofertilizers for compost use are cellulolytic fungal cultures and Azotobacter cultures. Vermicomposting is $100 \%$ unadulterated eco-accommodating natural manure; which has nitrogen, phosphorus, potassium, natural carbon, sulphur, chemicals, nutrients, catalysts and anti-microbial, whichimprove the quality and quantity of yield [9-11]. It is observed that, due to constant misuse of chemical fertilizers, the soil loses its productiveness and becomes saline day by day. To overcome this problem, natural farming and Vermicomposting is the best solution.

\section{Carriers}

Biofertilizers are carrier based fertilizer. The ideal carrier materials used in the preparation of biofertilizers must be cheaper, locallyavailable, and easier to process; must be non-hazardous and organic in structure (so that they remain biodegradable) with high water-holding capability; and should be able to carry more bacterial cells and allow their survival for longer durations. Certain commonly used carrier materials in the production of goodquality biofertilizers are neutralized peat, soil, lignite powder, vermiculite, charcoal, press mud, rock phosphate pellet, paddy straw compost, farmyard manure, and soil mixture [11].

\section{CONCLUSION}

Cow dung is conventionally applied in Indian Sub continental agriculture to improve soil fertility. In this context, organic farming using natural bioresources such as cow dung or an effective multifaceted bio-inoculant would enhance agricultural yield as well as maintain soil quality. Our conclusion suggests that microorganism present in cow dung can be used for preparation of bioinoculant or biofertilizer hence lessen the dependency on expensive approaches for improvement of plant growth.

\section{REFERENCES}

[1] Gupta, K. K., Aneja, K. R., \& Rana, D. (2016). Current status of cow dung as a bioresource for sustainable development. Bioresources and Bioprocessing, 3(1), 1-11. 
[2] Bhatt, K., \& Maheshwari, D. K. (2019). Decoding multifarious role of cow dung bacteria in mobilization of zinc fractions along with growth promotion of C. annuum L. Scientific reports, 9(1), $1-10$.

[3] Sharma, B., \& Singh, M. (2015). Isolation and characterization of bacteria from cow dung of desi cow breed on different morphobiochemical parameters in Dehradun, Uttarakhand, India. Int. J. Adv. Pharm. Biol. Chem, 4(2), 276-281.

[4] Bashan, Y. (1998). Inoculants of plant growth-promoting bacteria for use in agriculture. Biotechnology advances, 16(4), 729-770.

[5] Mishra, D., Rajvir, S., Mishra, U., \& Kumar, S. S. (2013). Role of biofertilizer in organic agriculture: a review. Research Journal of Recent Sciences, ISSN, 2277, 2502.

[6] Swain, M. R., Laxminarayana, K., \& Ray, R. C. (2012). Phosphorus solubilization by thermotolerant Bacillus subtilis isolated from cow dung microflora. Agricultural Research, 1(3), 273-279.

[7] Rathi, M., \& Gaur, N. (2016). Phosphate solubilizing bacteria as biofertilizer and its applications.
Journal of Pharmacy Research, 10(3), 146-148.

[8] Bhardwaj, D., Ansari, M. W., Sahoo, R. K., \& Tuteja, N. (2014). Biofertilizers function as key player in sustainable agriculture by improving soil fertility, plant tolerance and crop productivity. Microbial cell factories, 13(1), 1-10.

[9] Souza, R. D., Ambrosini, A., \& Passaglia, L. M. (2015). Plant growth-promoting bacteria as inoculants in agricultural soils. Genetics and molecular biology, 38(4), 401-419.

[10] Radha, T. K., \& Rao, D. L. N. (2014). Plant growth promoting bacteria from cow dung based biodynamic preparations. Indian Journal of microbiology, 54(4), 413-418.

[11] Nabi, S. U., Malik, G., \& Sharma, A. (2018). Trichoderma harzianum: a potential bioagent and plant growth promoter. 